\title{
Prospects of Mungbean as an Additional Crop in Rice Wheat System of Punjab Pakistan
}

\author{
Aziz-ur-Rehman, M. Ehsan Khan, Sadia Kaukab", Sajjad Saeed, M. Aqeel, Gulfam Riasat, \\ Ch. Muhammad Rafiq
}

Pulses Research Institute, Ayub Agricultural Research Institute (AARI), Pakistan

Copyright $\mathrm{C} 2019$ by authors, all rights reserved. Authors agree that this article remains permanently open access under the terms of the Creative Commons Attribution License 4.0 International License

\begin{abstract}
Mungbean is a beneficial as well as crucial pulse crop which has high economical and commercial values widely grown in Asia. It is cheap source of dietary protein, iron and minerals. It belongs to family Leguminosae and is valuable grain legume which comprises major portion of proteins, minerals, vitamins and essential amino acid. In Pakistan it ranks second in Pulses production after Chickpea. Mungbean suffers from several diseases due lack of good cultural practices and insight about the genome of this crop. These diseases caused by fungus, bacterium and viruses. Major diseases including Yellow Mosaic disease (YMD), Urdbean leaf crinkle disease (ULCD), Cercospora leaf spot disease (CLSD) and were caused by yellow mosaic virus, Cercospora canesens and Urdbean leaf crinkle virus respectively. Annually, 40-80\% grain yield losses were caused due to these diseases. To overcome these threats scientists/researchers are using approaches to develop resistant and high yielding Mungbean genotypes/cultivars. The area under Mungbean cultivation is decreasing day by day because most of varieties were matured at 100 to 120 days which were not suitable in our cropping pattern. There is a dire need to develop those varieties having high yield, resistant to diseases and insect pest, early and synchronize maturity (60-80 days).
\end{abstract}

Keywords Scenarios, Mungbean, Supplementary Crop, Rice-Wheat, Punjab Cropping Patterns

\section{Introduction}

Pulses area is continuously decreasing as pulses are unable to contest with major crops like wheat, cotton, sugarcane and rice. In pulses, Mungbean area has been decreased from 237,000 ha in 2002-03 to 118,000 ha in 2017-18. This decline is mainly due to replacement of Mungbean with Bt- cotton in chief Mungbean cultivating areas like; Bhakkar, Layyah and Mianwali districts. Now there is dire need to find out new niches for Mungbean cultivation. Rice wheat cropping system is a major cropping system of the Punjab, mainly in rice growing areas comprising of Sialkot, Gujranwala, Sheikhupura, Hafizabad, Okara, Nankana Sahib, Narowal, Mandi Bahauddin, Kasur, Jhang etc districts covering about 1.4 million ha which is about $30 \%$ of Punjab Thal area. Wheat is harvested during the last fortnight of April and the land remains vacant to the start of July till the transplanting of rice crop. In addition to that, both the crops are exhaustive in nature and results in soil nutrient depletion hence lowering the yield of both crops. There is a scope of sowing Mungbean as a catch crop from mid-April till the $1^{\text {st }}$ week of July. This will not only provide additional income to the farmers but owing to its nitrogen fixing ability will recover the soil fertility status of soil resulting in higher yield of both rice and wheat. Only if $25 \%$ of the rice wheat area of Punjab is brought under Mungbean catch crop, it can result in 427850 ha increase in area and 213925 tons increase in production which is $272 \%$ more than the current production level. This can not only help in attaining self-sufficiency in pulses but also improving quality of food by cereal pulses combination. The major issues which can curtail the popularization of Mungbean cultivation in rice wheat system as a catch crop are:

- Long maturity duration of current Mungbean varieties.

- $\quad$ Mungbean yellow mosaic virus (MYMV)

- Urdbean leaf crinkle virus (ULCV)

- Cercospora leaf spot disease (CLS)

As a good feature of its short duration and its ability to adopt in multiple sowing seasons Mungbean can fit very well in spacious display of niches space in the prevailing crop rotation. An additional crop of Mungbean can be assimilated in the un-cultivated period (May-June) after wheat harvest and before rice or maize plantation. In order to popularize Mungbean as an additional crop in between wheat and rice, early maturing (60 days) are required. The 
local Mungbean lines do not appropriate in the above niche due to their late maturity and are sternly affected by heat stressed in May-June and monsoon rains at harvesting if sown after wheat harvest. They also suffer from excessive growth and asynchronous maturity. If we succeeded in the development of short duration heat tolerant varieties of Mungbean it will be a major breakthrough to intensification in the outcome of the farmers and to enhance the soil fertility which ultimately enhance the production of both rice and wheat in these areas.

With the development of very early maturing (60 days), MYMD, CLS and LCD tolerant and synchronous maturing variety, it may become possible to grow Mungbean as a catch crop in Rice-Wheat cropping system of Punjab. Sowing of catch crop of Mungbean besides providing enough net cash returns over variable cost also add sufficient nitrogen $\left(37 \mathrm{~kg} \mathrm{ha}^{-1}\right)$ by which 25 percent nitrogen $(\mathrm{N})$ is saved for the subsequent crop (Sekhon et al., (2007).

In Pakistan, research work on Mungbean is mainly focused on the development of high yielding, disease resistant, large seeded and short duration varieties Patel (2011). There is an increase in yield per hectare from 477 $\mathrm{kg} \mathrm{ha}^{-1}(2001-02)$ to $793 \mathrm{~kg} \mathrm{ha}^{-1}$ but still a large gap exists between varietal potential and farmer's yield which needs to be fulfilled. Mungbean crop is exaggerated by numerous biotic and abiotic stresses. Habib et al., (2007) described that the vulnerability of Mungbean varieties to diseases and insect pests is the major cause of their low yield in Pakistan. Heavy losses under epiphytotic conditions have also been observed. A significant reduction in plant height (18.5 to $40.5 \%$ ), number of pods per plant (11.7 to $64.0 \%$ ), seeds per pod (5.8 to $82.2 \%)$, pod length (7.4 to $35.0 \%$ ), 1000 -seed weight (10.6 to $53.3 \%$ ) and grain yield per plant (32.2 to $78.6 \%$ ) due to MYMV disease has been observed (Khatak et al., 2000a).

\section{Mungbean Growing Areas}

Mungbean is a traditional pulse crop of Pakistan having $25 \%$ protein. Among the four provinces of Pakistan, Punjab is the major Mungbean-growing province that un-aided donates 86 and $87 \%$ of area and production, respectively (Anonymous, 2012-13). Seed yield of Mungbean per acre is very low which is due to low varietal potential along with poor management practices. Contrary to the other major crops, Mungbean can be efficaciously cultivated on marginal lands with low inputs. It is the second major pulse crop in these areas. Major production area comprises the southern part of the Punjab province especially Bhakkar, Layyah and Mianwali Districts.

In Punjab; Gujranwala, Sialkot, Sheikhupura, Hafizabad, Okara, Nankana Sahib, Jhang, Narowal, Mundi Bahauddin and Kasur are the major rice growing districts. In Punjab rice has been grown on an area of 1711.4 thousand hectares, which account 74\% of Pakistan rice area (Anonymous 2012-13). Rice-Wheat cropping system delivers constant productivity and better income to the farmers. In addition, this system facilitated greatly in industrial expansion, employment facilities and economic growth of the country. Though, it is prompting solemn problems like absolute fall in water table, more swarm by diseases and insect pests and exhaustion of soil fertility etc. According to an estimate, Rice-Wheat system can eliminate more than $650 \mathrm{~kg} \mathrm{ha}^{-1}$ nitrogen and phosphorus because this system observed to be highly exhaustive (Shah et al., 2011). Depletion of soil nutrients observed to be occurs in Rice-Wheat system and in long term productivity was also observed to be affected. In addition to that such a system results in negative nitrogen balance in the soil although all the crops grown under this system have been provided with recommended doses of fertilizer (Shah et al., 2003). To combat soil nutrient problems farmers used chemical fertilizers which are highly expensive. The application of expensive fertilizers is not possible in developing countries. Wheat is harvested during the month of April and the land remains vacant from end of April to mid of July till the transplanting of rice crop. In addition to that both cereal crops have been continuously grown in these districts year after year and no other rotation has been practiced, which is very dangerous for soil fertility and may be the major reason of soil nutrients depletion. Incorporation of a leguminous crop in Rice-Wheat system helps in maintaining the $\mathrm{N}$ level of soil. It also improves mineralized $\mathrm{N}$ contents of soil and organic carbon (Shah et al., 2003; Shafi et al., 2007; Abbasi et al., 2009 and Bukht et al., 2009). To fill the gap between wheat harvesting and rice transplanting and to enhance the nutrients status of the soil there is a dire need to grow some leguminous crop on that area during the month of April-June which may increase soil fertility through biological nitrogen fixation and help to increase organic matter of the soil in addition to the extra income. Positive impact of inclusion of summer legumes (Mungbean) in Rice-Wheat System was observed in Pakistan (Mann, 2000). Legumes contribute substantially to paddy yield straw and nitrogen status of soil.

\section{Major Yield Limiting Factors}

Any disturbance in the metabolic processes caused by various biotic and abiotic stresses confronted by the plant may lessen the actual yield. The harshness of various anxieties is basically due to wobble weather conditions that triumph year after year, thus decreasing pulses yield at farmer's field and potential yield. Low yielding cultivars and susceptibility to diseases i.e. Mungbean Yellow Mosaic Disease (MYMD), Cercospora Leaf Spot (CLS) and Urdbean Leaf Crinkle Disease (ULCD) which are the major diseases of Mungbean particularly. 
MYMD transmitted by white fly (Bemisia tabaci Genn.) is the foremost limitation causing low seed yield. White fly persistently transmits Mungbean yellow mosaic virus (MYMV) and infects all growth stages of Mungbean (Honda and Ikegami, 1986). Among the viral diseases, Mungbean yellow mosaic virus is very devastating in Pakistan particularly in summer season. The disease is characterized by the manifestation of yellow flecks or dots on young leaves and the auspicious trifoliate leaves evident uneven yellow and green patches causing reduction in leaf size. In severe cases there is complete yellowing of leaves followed by stunted growth, few flowers and pods with shriveled seeds. Disease incidence ranges between $30-100 \%$ causing yield losses that range between $60-80 \%$, depending upon the disease severity and the crop stage at which plants get infected. The incidence of MYMV has been detected and identified in commercial plots of Mungbean in Pakistan and range from 4 to $40 \%$ depending upon crop variety and location in Pakistan have been reported (Bashir et al., 2006). However, in naturally infected susceptible cultivars it varies with the time of infection and yield losses may reach up to $100 \%$ (complete crop failure). Apart from Pakistan MYMD is the crucial hazard to Mungbean production in India, Sri Lanka, Bangladesh, Papua New Guinea, Philippines and Thailand (Honda et al., 1983; Chenulu \& Verma, 1988; Malik \& Bashir, 1992; Jones et al., 2003) and inflicts heavy yields losses annually. MYMD is caused by Mungbean yellow mosaic begomoviruses belonging to family Geminiviridae. Like other begomoviruses its viral particles are isometric and germinate having 18 to $30 \mathrm{~nm}$ in size with two single stranded DNA molecules (DNA A \& DNA B) of 2726 and 2775 nucleotides, respectively (Bos, 1999 and Hull, 2004). This virus is spread by whitefly (Bemisia tabaci Genn) and through grafting but not through seed, sap and soil (Nair and Nene, 1973 and Bashir 2003). Mungbean Yellow Mosaic Virus (MYMV) may render a resistant variety to become susceptible to some extent after a certain period when new viral strains are produced. Thus, varieties generally appear to be resistant or tolerant at one location may show susceptible behavior at another location. It has been noted that a single recessive gene is responsible for MYMV resistance in Mungbean Sehrawat et al., (2015). The expression of major gene responsible for MYMV resistance/susceptibility was affected by modifying genes which were also found to be equally responsible for the inheritance of MYMV (Khattak et al. 2000b and Akhtar et al., 2016).

The pathogen resources of MYMV resistance have not been identified. However, Vigna species isolates MYMV were used to evaluate and distinguish the susceptibility reaction against the disease (Sudha et al., 2014). The disease occurs over a wide range of climatic conditions in summer and the resistance against this disease was found to be scarce in Mungbean germplasm (Shad et al. 2006). Incorporation of resistant genes in the present cultivars is the only practical way to control viral diseases (Bashir et al., 2006) and diminishes heavy yields losses annually. Initially the disease appears as small yellow spots along the veins on young leaves and then spread over the leaves. Under severe infection, the characteristic symptoms include yellowing or chlorosis of entire leaf on whole plant followed by necrosis, shortening of internodes, severe stunting of plants with no yield or few flowers \& deformed pods producing small, juvenile and shriveled seeds (Akhtar \& Haq, 2003; Bashir et al., 2006 and Akhtar et al, 2009).

Cercospora Leaf Spot (CLS), a fungal disease caused by Cercospora canesens is distributed by spores of infected leaves. Characteristic symptoms include leaf spots with brown to greyish center and reddish-brown border. This is an imperative disease of Mungbean and is usually occurs in severe form, causing heavy yield losses. Cercospora Leaf Spot causes severe yield losses to Mungbean; upto 23\% and $47 \%$ and is a serious disease in Mungbean growing areas of Pakistan especially where high humidity prevails. During rainy season hot and humid conditions are favorable to encounter this disease. It starts appearing after 35 days of planting, spreads rapidly depending on the humidity during growing season and causes premature defoliation of pods and grains. Severe leaf spotting and defoliation arises at the time of flowering and pod formation under conditions favorable for this disease (Bashir \& Zubair, 1985).

Leaf crinkle disease (LCD) originated by Urdbean Leaf Crinkle Virus (ULCV) is a very serious disease, widely distributed in Pakistan (Bashir \& Zubair, 1985). In Pakistan, $35 \%$ to $81 \%$ grain yield losses due to ULCV has been reported, depending on genotype and time of infection (Bashir et al., 1991).The virus has been reported to be transmitted by Aphid species (Aphis craccivora and A. gossypii), whitefly (Bemisia tabaci) and leaf hoppers (Narayansamy \& Jaganthan 1973).The disease starts appearing within 5 weeks after sowing and is characterized by crumpling, curling and wrinkling of leaves often tied with stunting and irregularity of floral organs. Improvements in size trail by crinkle surface of lamina are the distinctive symptoms on affected trifoliate leaves. Pollen production, fertility and consequent pod formation is sternly reduced thus affecting seed weight and size of seeds in infected plants primary to decrease in yield.

Mungbean crop may be sown in the $1^{\text {st }}$ week of May after harvest of wheat and harvested 60 days after sowing to ensure timely plantation of rice crop. Limited availability of short duration, photoperiod insensitive and heat tolerant cultivars limits the adoption of this practice, so during the development of new Mungbean genotypes for rice wheat system, these factors must be given due consideration. Although current Mungbean varieties have the ability to produce good yield (Table 1) when Mungbean is sown as catch crop in between wheat and rice crops. The main problem of popularizing this crop is maturity duration of current varieties like MN-2011 and 
AZRI M-2006, which take about 70-75 days to mature.

Table 1. Yield data of Mungbean catch crop trials conducted at farmers field in Rice Wheat cropping system conducted under AIP-AVRDC Project.

\begin{tabular}{|c|c|c|c|c|}
\hline Year & Location & $\begin{array}{c}\text { Area } \\
\text { planted } \\
\text { (ha) }\end{array}$ & \multirow{2}{*}{ Variety } & $\begin{array}{c}\text { Yield } \\
\text { (kg/ha) }\end{array}$ \\
\hline \multirow{2}{*}{2015} & Chandikot & 4.25 & \multirow{2}{*}{ NM-2011 } & 1170 \\
\cline { 2 - 3 } & Farooqabad & 1.62 & & 1297 \\
\hline \multirow{2}{*}{2014} & Chandikot & 31.2 & \multirow{2}{*}{ AZRI M-06 } & 1500 \\
\cline { 2 - 3 } & Farooqabad & 3.80 & & 510 \\
\hline
\end{tabular}

\section{Synchronous Maturity}

For finding good yield of catch crop of Mungbean synchronous maturity is compulsory along with early maturity. Earlier quite a few researchers detailed positive effect of synchronous pod maturity in seed yield (Pierre et al., 2003; Hamid et al., 2004 and Chen at al., 2008). Stimulation of flowering and synchronous renovation from vegetative phase to the floral opening is an imperative stage of synchronous maturity (Corbesier et al., 2003).

The time of pod maturation is a vital feature in the synchronous pod maturation and in classification on the degree of indetermination of growth period may simplify to approve suitable and well-organized plant breeding approaches to develop high yielding Mungbean genotypes with synchronous growth pattern (Shgarma-Natu \& Ghildiyal, 2005). The term degree of indetermination has been used to exemplify modification from days to first flowering $\left(\mathrm{D}_{1}\right)$ to $90 \%$ pod maturity $\left(\mathrm{D}_{3}\right)$ in Mungbean (Vigna radiata L. Wilczek) (Khattak et al., 2001). In spite of the position of synchronous maturity, Mungbean pod ripening is not synchronous (Yeates et al., 2000), irregular pod maturity primes to low yield and low harvest index (HI) in Mungbean (Bushby \& Lawn, 1992 and Egli \& Bruening, 2006). A high harvest index means high percentage of seed yield in total biomass production. Thus, in order to increase the seed yield, selection of higher harvest index genotypes could be accomplished through synchronous maturity. The contrary possessions on seed yield due to high leafiness and synchronous flowering have been observed (Bisht et al., 1998 \& 2005). Cultivation of Mungbean in fallow period between wheat and rice crop pledges a good backup of worth Rs. 30,000 to 40,000 per acre by investing a little amount on seed and irrigation. Growing of Mungbean also improves fertility status of soil and increases yield of the succeeding crops.

\section{REFERENCES}

[1] Abbasi, M.K., M.M. Tahir, A.H. Shah and F. Batool (2009). Mineral nutrient composition of different ecotypes of white clover and their nutrient credit to soil at Rawalakot Azad Jammu and Kashmir. Pak. J. Bot., 41(1): 41-51.

[2] Akhtar, K. P. and M. A. Haq (2003) Standardization of a graft inoculation method for the screening of Mungbean germplasm against Mungbean yellow mosaic virus (MYMV). Plant Pathol. J. 19: 257-259.

[3] Akhtar, K. P., R. Kitsanachandee. P. Srinives, G. Abbas, M.J. Asghar, T.M. Shah, B.M. Atta, O. Chatchawan kanphanich, G. Sarwar, M. Ahmad and N. Sarwar (2009) Field evaluation of Mungbean recombinant inbred lines against Mungbean yellow mosaic disease using new disease scale in Thailand. Plant Pathol. J. 25: 422-428.

[4] Akhtar, J., H. M. Lal, P. K. Singh, S. Karmakar, N. K. Gautamand and A. Kumar (2016). Identification of resistant sources of vigna spp. against Yellow Mosaic Disease. Virol. Mycol. 5:1.

[5] Ali, M., and S. Kumar (2006). Mungbean and Urdbean: Retrospect and prospects. Advances in Mungbean and Urdbean. Indian Inst. of Pulses Res. Kanpur, 1-19.

[6] Anonymous, 20011-12. Economic Survey of Pakistan. Government of Pakistan, Finance Division, Economic Advisor's Wing, Islamabad.

[7] Anonymous, 20012-13. Economic Survey of Pakistan. Government of Pakistan, Finance Division, Economic Advisor's Wing, Islamabad.

[8] Bakht, J., M. Shafi. M.T. Jan and Z. Shah (2009) Soil C and $\mathrm{N}$ dynamics and wheat yield as affected by cropping systems and residue management in North Western Pakistan. Soil and Tillage Research. 104: 233-240.

[9] Bashir M and M. Zubair (1985) Survey of kharif pulses in Islamabad. Rawalpindi and Sialkot Distt, PARC, Islamabad. Pulses Programme Survey Report 2002, pp-15.

[10] Bashir M and M, Zubair (2002) Identification of resistance in Urdbean (Vinga mungo) against two different viral diseases. Pak. J Bot., 34(1): 49-51

[11] Bashir, M. (2003) Studies on viral disease of major pulse crops: Identification of resistant sources. Ann. Tech. Rep. PARC for 2003-2004. $76 \mathrm{pp}$.

[12] Bashir, M., S.M. Mughal and B.A. Malik. (1991) Assessment of yield losses due to Urdbean leaf crinkle virus in Urdbean, Vigna mungo (L.) Hepper. Pak J Bot. 23: 140-142.

[13] Bashir, M., Z. Ahmad, and S. Mansoor (2006) Occurrence and distribution of viral disease of Mungbean and Mash bean in Punjab, Pakistan. Pak. J. Bot. 38: 1341-1351.

[14] Bisht I. K. Bhat, S. Lakhanpaul, M. Latha, P. Jayan, B. Biswas and A. Singh (2005) Diversity and genetic resources of wild Vigna specie in India. Genetic Resources Crop Evol. 52: 53-68.

[15] Bisht, I., R. Mahajan and D. Patel (1998) The use of characterization data to establish the Indian Mungbean core collection and assessment of genetic diversity. Genetic Resources Crop Evol. 45: 127-133.

[16] Bos, L (1999) Plant Viruses: Unique and Intriguing Pathogens: A Text Book of Plant Virology, Backhuys Publishers, Netherlands. 305-306 pp. 
[17] Bushby, H. and R. Lawn, (1992) Accumulation and partitioning of nitrogen and dry matter by contrasting genotypes of Mungbean (Vigna radiata L. Wilezek) Austalian J. Agric. Res. 43: 1609-1628.

[18] Chen, L., A Markhart, S. Shanmugasundaram and T. Lin (2008). Early developmental and stress responsive ESTs from Mungbean, (Vigna radiata L. Wilczek) seedlings. Plant Cell Reports 27: 535-552.

[19] Chenulu, V. V. And A. Verma (1988) Virus and virus-like diseases of pulse crops commonly grown in India. In: Baldev, B., S. Ramajunam and H.K. Jain (eds.) Pulse Crops, New Delhi, Oxford and IBH. 338-370.

[20] Corbesier, L., I. Gadisseur, G. Silvestre, A. Jacqmard and G. Bemier, (2003) Design in Arabidopsis thaliana of synchronous system of floral induction by one long day. Plam J. 9: 947-952.

[21] Dhole, V. J. and K. S. Reddy (2012). Genetic analysis of resistance to Mungbean Yellow Mosaic Virus in Mungbean (Vigna radiata L.). Plant Breed. 131 (3): 414-417.

[22] Egli, D. and W. Bruening (2006) Fruit development and reproductive survival in soybean. Position and age effects. Field Crops Res., 98:195-202.

[23] George, C. K., L. Chien, R. Ramakrishnan and M. Nair (2013). The major quantitative trait locus for yellow mosaic Indian virus resistance is tightly linked in repulsion phase to the major bruchid resistance locus in a cross between Mungbean [Vigna radiata (L.) Wilczek] and it wild relative Vigna radiata spp. Sublobata. Euphytica 192: 205-2016.

[24] Habib, S., N. Shad, A. Javaid and U. Iqbal (2007) Screening of Mungbean germplasm for resistance/tolerance against yellow mosaic virus. Mycopath 5(2): 89-94.

[25] Hamid S and D.J. Robinson (2004) Begomoviruses form Mungbeans in Pakistan: epitype profiles. DNA A sequence and phytogenic relationships. Arhives virol., 149:809-819.

[26] Haque, A. H., Mehfuzul, M. M. kamal and A. M. Akhanda (2012). Effect of four selected chemicals on the incidence and severity of Mungbean Yellow Mosaic virus and its relation to the seed yield Mungbean. Int. J. Food Sci. Eng. 2(9): 51.

[27] Honda, Y., M. Iwaki, and Y. Saito (1983) Mechanical transmission, purification and some properties of whitefly-borne Mungbean yellow mosaic virus in Thailand. Plant Dis. 67: 801-804.

[28] Honda, Y and M. Ikegami. 1986. Mungbean Yellow Mosaic Virus. CMI/AAB Description of plant viruses. pp: 323.

[29] Hull, R. (2004) Mathew's Plant Virology, Forth Edition. Elsevier Publishers, India. 180-182 pp.

[30] Iqbal, S. M., M. A. Zahid and S. H. Khan (2009). Screening of local Mungbean germplasm against Cercospora leaf spot disease. Pakistan J. Phytopathol. 423: 123-125.

[31] Iqbal U., M. I. Sheikh, A. Rukhsana, J. Atif, A. F. Muhammad and Z. Ashraf (2011). Screening of Mungbean germplasm against Mungbean Yellow Mosaic Virus (MYMV) under field conditions. Pakistan J. Phytopathol. 23 (1): 48-51.

[32] Jones, D. R (2003) Plant viruses transmitted by whiteflies.
Eur. J. Plant Pathol. 109: 195-219.

[33] Khattak, G., M. Haq, M. ashraf and G. Tahir (2001) Genetic basis of Synchronomy in pod maturity in Mungbean (Vigna radiata L. Wilczek). Kasetsart J. Nat. Sci., 35: 1-7.

[34] Khattak, G.S.S, M.A Haq, M. Ashraf, and G.R. Tahir (2000a). Heterosis for some morphological traits in Mungbean (Vigna radiata L. Wilczek). Kasetsart J. Nat. Sci., 34(4): 439-442.

[35] Khattak, G.S.S, M.A Haq, M. Ashraf, and M.A. Awan (2000b). Inheritance of plant and flower bud colour in Mungbean (Vigna radiata L. Wilczek). Songklanakarin J. Sci. Technical. 22(2):249-251.

[36] Malik, B. A., and M. Bashir (1992). Major diseases of food legume crops of Islamic countries. In proceedings of COMSTECH-NIAB International workshop of agroclimatology pests and disease and their control. Jamil, (F. F and S. H. M. Naqvi eds.) 25-38 pp.

[37] Mann, R.A., M.S. Zia and M. Salim (2000). New dimensions in green manuring for sustaining the productivity of rice wheat system. In Proceedings of symposium on Integrated Plant Nutrition Management (N. Ahmad and A Hamid. eds). November 8-10. 1999, 166-185pp. National Fertilizer Development Centre, Islamabad.

[38] Nadarajan, N and G. Sanjeev (2010). Role of classic breeding in improvement of pulse crops. Electronic J. Plant Breed. 1(4): 1099-1106.

[39] Nair, N. G. and Y.L. Nene (1973). Studies on yellow mosaic of urdbean (Phaseolus mungo) caused by Mungbean yellow mosaic. Transmission studies. Indian Frmg. Sci., 1: 109-110.

[40] Narayansamy P. and T. Jaganthan (1973). Vector transmission of blackgram leaf crinkle virus. Madrad Agricultural Journal. 6: 651-652.

[41] Patel, H. P. 2011. Physiological and biochemical changes induced by the MYMV in Mungbean (Vigna radiata (L.) Wilczek) and management of diseases through vector control. pp: 1-71.

[42] Pierre, T., C. Laurent, H. Andree, P. Alexandra, K. Eniule, B. Georges and P. Claire (2003) A novel high efficiency, low maintenance hydroponic system for synchronous growth and flowering of Arabidopsis thaliana. Plant Biol. 3: 1-10.

[43] Sehrawat, N., M. Yadav, K. V. Bhat, R. K.Sairam, P. k. Jaiwal (2015). Introgression of Mungbean yellow mosaic virus resistance in Vigna mungo (L). Hepper and purity testing of F1 hybrids using SSRs. Of resistance to Cercospora leaf spot in Mungbean. AVRDC, Taiwan, 213-217.

[44] Sekhon, H. S., T. S. Bains, B. S. Kooner, and P. Sharma (2007) Growing summer Mungbean for improving crop sustainability, farm income and malnutrition. ACTA Horticultural 752: 459-464.

[45] Shad N, SM. Mughal, K. Farooq, M. Bashir (2006) Evaluaiton of Mungbean Germplasm for resistance against Mungbean Yellow Mosaic Begomovirus. Pak. J. Bot., 38(2): 449-457.

[46] Shafi, M., J Bakht, M.T. Jan and Z. Shah (2007) Soil C and $\mathrm{N}$ dynamics and maize (Zea mays L.) yield as affected by 
cropping systems and residue management in North Western Pakistan. Soil and Tillage Research, 94: 520-529.

[47] Shagrma-Natu P. and M. Ghildiyal (2005) Potential targets for improving Photosynthesis and crop yield. Curr. Sci. 88: $1918-1928$

[48] Shah Z. and A.A. Khan. 2003. Evaluation of crop residues for potentially available nitrogen in soils. Sarhad Journal of Agriculture, 19: 81-92.

[49] Shah, Z., S.R. Ahmad and H. Rehman (2011) Sustaining rice wheat system through management of legumes Pak. J. Bot
43: $1569-1574$.

[50] Shah, Z., S.H. Shah, M.B. Peoples, G.D. Schwenke and D.F. Herridge (2003) Crop residue and fertilized N effects on nitrogen fixation and yields of legume-cereal rotations and soil organic fertility. Field Crops Research, 83:1-11.

[51] Shuda, M., A. Karthikeyan, P. Anusuya, N. M. Ganesh, M. Pandiyan, N. Senthil, M. Raveendran, P. Nagarajan and K. Angappan (2013). Inheritance of resistance to Mungbean yellow Mosaic Virus (MYMV) in inter and intra-specific crosses of Mungbean (Vigna radiata L.). Am. J. Plant Sci. 4: 1924-1927. 